DOI: 10.32089/WBH.phw.2019.2(268).0005

orcid.org/0000-0003-3258-0540

TomAsz KROK

\title{
Przypadek dezercji dowódlcy oddziału radiotelegraficznego w I Korpusie Polskim w Rosji Zygmunta Włodzimierza Tarły-Mazińskiego
}

6 sierpnia 1917 r. generał Józef Dowbor-Muśnicki przystąpił do tworzenia I Korpusu Polskiego, składającego się z żołnierzy polskich wywodzących się z armii rosyjskiej, służących na Froncie Zachodnim i Froncie Północnym. Wojska te, według założeń Naczelnego Polskiego Komitetu Wojskowego, miały być skierowane do walki z Niemcami, jednak napięta sytuacja wewnętrzna w Rosji (rewolucja październikowa) pokrzyżowała te plany ${ }^{1}$. $\mathrm{Z}$ powodu niepowodzenia $\mathrm{w}$ początkowych próbach pertraktacji $\mathrm{z}$ bolszewikami tymczasowe zawieszenie broni zostało zerwane i doszło do walk. Objęły one m.in. rejon Bobrujska, który został zdobyty przez Polaków na początku lutego 1918 r. W styczniu Dowbor-Muśnicki wydał rozkaz wyjazdu części Korpusu do Twierdzy Bobrujsk. Po wyzwoleniu Mińska Litewskiego przez Polaków, na mocy porozumienia ze sztabem niemieckim, polskie oddziały musiały opuścić miasto 27 lutego $1918 \mathrm{r}^{2}$

Pisarz Melchior Wańkowicz, ówczesny żołnierz I Korpusu, w swojej krytycznej względem gen. Dowbora-Muśnickiego książce Strzępy epopei, wydanej w 1923 r., opisał ten okres następująco: „Oddziały nasze są rozrzucone po obszarach guberni mińskiej, witebskiej, smoleńskiej. Pomiędzy tymi oddziałami znajdują się całe miasta, olbrzymie garnizony, pozostałe po

\footnotetext{
1 W. Lipiński, Walka zbrojna o niepodległość Polski w latach 1905-1918, Warszawa 1990, s. 249 .

2 „Wskutek porozumienia się z dowódç̨ korpusu, Niemcy zażądali opuszczenia Mińska przez oddziały polskie dnia 27 II 1918 r. o godz. 18-ej wieczorem”. H. Bagiński, Wojsko Polskie na Wschodzie: 1914-1920, Warszawa 1990, s. 241.
} 
likwidującym się froncie [...]. Dowództwo Korpusu wydaje rozkaz koncentracji w rejonie Bobrujska. Bobrujsk, jak na potrzeby wojny domowej, jest silną twierdzą i można się w nim długo trzymać. Ale dowództwo samo nie wierzy, by rozkaz ten został spełniony. Morale żołnierza jest pod psem. Jakże by mogło być inne, jeśli werbowano go nie pod hasłem walki, a powrotu do kraju, nie pod hasłem ofiary, a wygody?"3

Przypadki dezercji i problemy z karnością w I Korpusie Polskim były częste. Większość żołnierzy rekrutowała się z chłopów oraz robotników, przez co efektywnie oddziaływała na nich agitacja bolszewicka, powodując stale powiększającą się dezercję. Bolszewicy zarzucali Muśnickiemu brak „demokratyzacji” w Korpusie, rozumianej jako tworzenie w armii „komitetów" wybierających dowódców spośród siebie ${ }^{4}$. Za pomocą artykułów prasowych, ulotek oraz działalności propagandystów i emisariuszy bolszewickich prowadzono kampanię propagandową. Nawoływano żołnierzy do pozostania w „demokratycznym” wojsku rosyjskim, które szanuje zdobycze rewolucji w przeciwieństwie do "pańsko-burżuazyjnego" wojska polskiego ${ }^{5}$.

Proceder dezercji w I Korpusie Polskim dotyczył nie tylko żołnierzy szeregowych, lecz także oficerów. Jak pisał po latach gen. Dowbor-Muśnicki na łamach swoich wspomnień: „Rewolucja rosyjska rozprzęgła dyscyplinę i doprowadziło do tego, że o potrzebie jej istnienia zapominali nie tylko Polacy szeregowi, ale i niektórzy oficerowie ${ }^{6}[. .$.$] Ci panowie tylko dlatego$ wkładali na siebie mundury korpusowe, by być nakarmieni, ubrani, zapłaceni a po za tym mieć możność krytykowania wszystkiego z ukrycia, no i zohydzania. Za wszelką cenę unikali oni udziału w walkach, a nawet unikali szeregów poza walkami"?.

Zjawisko to nie było wyjątkowe dla formacji polskich na wschodzie, jak podaje w swoim artykule Dezercje i unikanie stużby w Wojsku Polskim Remigiusz Kasprzycki, cytując przy tym wspomnienia legionisty Mieczysława Lepeckiego: „Dla części rekrutów służba w WP okazała się trudnym wyzwaniem, nie wszyscy podołali wojskowej dyscyplinie. Jednak w pierwszej fazie kształtowania się WP zjawisko dezercji było bagatelizowane, a wręcz pożądane. W kręgach

\footnotetext{
3 M. Wańkowicz, Strzępy epopei: Szpital w Cichiniczach; Wrzesień żagwiący; Po klęsce, Warszawa 2009, s. 48.

4 Jak pisał gen. Dowbor-Muśnicki w Moich wspomnieniach: „Przecież chłop polski jest dobrym materiałem żołnierskim, ale brakowało mu uświadomienia. Zamarł w nim duch wojowniczy, wolał wycierać tyły i zasiadać w komitetach". J. Dowbor-Muśnicki, Moje wspomnienia, Poznań 2013, s. 299.
}

5 Zdaniem Henryka Bagińskiego: „Energiczna agitacja żywiołów lewicowych obałamucała żołnierza polskiego hasłem szybkiego powrotu do kraju i pozostawania nadal w szeregach «demokratycznej» armji rosyjskiej”. H. Bagiński, Wojsko Polskie..., s. 145.

6 J. Dowbor-Muśnicki, Moje wspomnienia...., s. 266.

7 Ibidem, s. 316. 
wojskowych traktowano je jako naturalną selekcję. Bardzo liczne dezercje oznaczały w końcu 1918 roku oddzielenie plew od ziaren. Jak wspominał w 1936 roku Mieczysław B. Lepecki: «Podówczas [to jest w grudniu $1918 \mathrm{r}$. - R.K.] znajdowało się w kompaniach wielu ludzi o przeszłości dość ciemnej, »bolszewickiej«. Jednak już w drugiej połowie grudnia zauważyłem, że wszystkie takie podejrzane typy zaczęły jeden po drugim znikać. Po prostu dezerterowali. Byłem $\mathrm{z}$ tego zupełnie rad i wcale im nie przeszkadzałem»" ten pokazuje, że dezercje niekiedy traktowano jako szansę na uzdrowienie relacji panujących w wojsku. W podobny sposób zdawał się podchodzić do tego problemu w I Korpusie gen. Józef Dowbor-Muśnicki, który w styczniu 1918 r., zwracając się do 1 Dywizji Strzelców, zaproponował: „żeby ci, którzy chcą walczyć dalej [...] zostali, ci zaś którzy nie chcieliby walczyć, opuścili szeregi. Postąpiłem tak dlatego, że dezercja w oddziałach rosła w sposób zastraszający - jak zaznaczał - Chciałem się upewnić, że ci którzy pozostaną rzeczywiście walczyć będą do ostatka"'.

Z akt sztabu I Korpusu Polskiego wynika, że żołnierze, którzy dopuszczali się dezercji, byli w większości wydalani z I Korpusu Polskiego, a oficerowie wpisywani przez dowódców na „czarne listy” wraz z tymi, którzy dopuszczali się innych nieżołnierskich zachowań (kradzieży czy nielegalnego handlu ${ }^{10}$ ). Treść „,czarnych list” głosiła, że osoby, które się na nich znalazły, „pod żadnym pozorem nie mogą być nie tylko $\mathrm{w}$ formacjach wojsk polskich, ale i zajmować żadnych stanowisk w instytucjach" ${ }^{\prime 1}$. Co ciekawe, zdarzały się także przypadki powtórnego włączania dezerterów w skład I Korpusu z powodu niedoborów kadrowych, jednak osoby takie degradowano do stopnia szeregowca ${ }^{12}$.

8 R. Kasprzycki, Dezercje i unikanie stużby w Wojsku Polskim w latach 1918-1939, „Dzieje Najnowsze" 2016, nr 3, s. 87.

$9 \quad$ J. Dowbor-Muśnicki, Moje wspomnienia..., s. 299.

10 Centralne Archiwum Wojskowe Wojskowego Biura Historycznego (dalej: CAW-WBH), I Korpus Polski - Oddzielna Radiotelegraficzna Grupa, sygn. I.122.49.42, Rozkaz nr 45 do Pierwszego Korpusowego Radiotelegraficznego Oddziału w związku ze zbiegłymi szeregowcami, 9 III 1918 r., b.p.

11 CAW-WBH, I Korpus Polski - Sztab korpusu, sygn. I.122.1.97, Lista oficerów i żołnierzy 1 batalionu strzelców, których należy zapisać na czarną listę podpisana przez płk. Józefa Kopytyńskiego, b.d, b.p.; Spis żołnierzy 9 pułku I Korpusu Polskiego, którzy byli wpisani na czarną listę podpisana przez płk. Alnina, b.d., b.p.

12 „Wszystkich nowo przybywających żołnierzy polskich, którzy w chwilach krytycznych uciekli z szeregów ojczystych, a obecnie zjawiają się, lecz przeważnie z pobudek natury czysto zoologicznej (strach przed obozem koncentracyjnym, robotami przymusowymi, głodem, etc.) wciągnąć na nowo na listy pułków, tylko jako szeregowców, pozbawiając ich poprzednich rang". CAW-WBH, I Korpus Polski - Oddzielna Radiotelegraficzna Grupa, sygn. I.122.49.42, Załącznik podpułkownika Bolesława Jaźwińskiego do Rozkazu por. Giedroycia do Pierwszego Korpusowego Radiotelegraficznego Oddziału, nr 50, 14 III 1918 r., b.p. 
Przypadkiem posiadającym niewątpliwie znamiona dezercji była sprawa ppor., pierwszego dowódcy oddziału radiotelegraficznego I Korpusu Polskiego, Zygmunta Włodzimierza Tarły-Mazińskiego. Urodzony 28 kwietnia 1889 r. w rodzinie inżyniera budowlanego Władysława, był absolwentem Gimnazjum im. gen. Pawła Chrzanowskiego w Warszawie, które ukończył w 1914 r. Później podjął roczne kursy inżynieryjne w Pawłowskiej Szkole Wojskowej oraz Oficerskiej Szkole Elektrotechnicznej w Piotrogrodzie. Następnie został mianowany naczelnikiem szkoły w oddziałach radiotelegraficznych armii rosyjskiej, wykładowcą elektro- i radiotechniki na oficer-

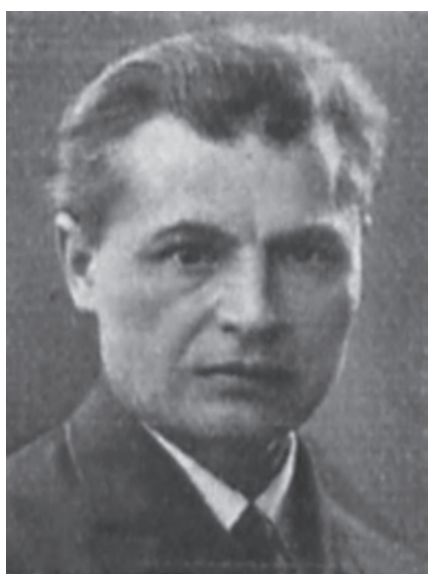

Zdjęcie Zygmunta Włodzimierza Tarły-Mazińskiego z książki Czy wiesz kto to jest?, red. S. Łoza, Warszawa 1938 skich kursach przy sztabie Frontu Zachodniego oraz dowódcą korpusowego oddziału radiotelegraficznego. W 1917 r. otrzymał funkcję wojskowego inżyniera radiotechnika. $Z$ tego okresu pochodzą jego podręczniki w języku rosyjskim: Элементарная радиотелеграбия и радиотелебония с общим курсом электротехники (1915) і Элементарная радиотелеграбия и радиотелебония с общим курсом электротехники (1917), które zostały wydane później po polsku jako: Elementarna radiotelegrafia i radiotelefonia $z$ pobieżnym kursem elektrotechniki (1917) oraz Zasady radiotelegrafii (1919). Były to pierwsze polskie publikacje traktujące o radiotelegrafii wojskowej ${ }^{13}$. Jesienią $1917 \mathrm{r}$. Tarło-Maziński wszedł w skład tworzących się w Rosji polskich sił zbrojnych, gdzie w stopniu ppor. został pierwszym dowódcą oddziału radiotelegraficznego i komendantem szkoły radiotelegraficznej przy sztabie I Korpusu Polskiego ${ }^{14}$.

We wspomnieniach gen. Dowbora-Muśnickiego, wydanych po raz pierwszy w 1935 r., Tarło-Maziński został wymieniony z nazwiska z konkretnym zarzutem dezercji i sugestią, że sympatyzował z bolszewikami: „Otóż Niemcy nie są tak przezorni, za jakich przywykliśmy ich uważać. Przegapili radiostację w Bobrujsku, z której oczywiście skwapliwie, aż do demobilizacji, korzystałem. Rozporządzałem dwoma dzielnymi oficerami radiotelegrafistami Sroką i Giedroyciem oraz kilkoma żołnierzami. To wszystko co zostało po walkach $\mathrm{z}$ bolszewikami z dobrze zaopatrzonego oddziału radiotelegraficznego; dowodził nim kapitan Tarło-Maziński, który,

13 J. Kubiatowski, Zygmunt Włodzimierz Tarło-Maziński, „Polski Słownik Biograficzny” (Wrocław) 1975, t. 15, s. 300.

14 CAW-WBH, AP 1769/89/5221, Tarło-Maziński Zygmunt, Odpis wyciągu z karty ewidencyjnej kapitana A.O. Tarły-Mazińskiego, ref. oświat. Baonu Zap. radio., b.d., b.p. 
grawitując do bolszewizmu, rozkazu mojego przyjścia do Bobrujska nie wykonał i gdzieś zniknął"15.

Z akt 1 Polskiego Oddziału Radiotelegraficznego wynika, że oddział po przejęciu przez wspomnianego por. Włodzimierza Giedroycia był w opłakanym stanie, liczył jedynie 18 osób i funkcjonował w nim tylko jeden aparat telefoniczny ${ }^{16}$. W drugiej połowie lutego 1918 r. większość składu 1 Polskiego Oddziału Radiotelegraficznego zdołała przebić się do twierdzy z rozkazu gen. Dowbora-Muśnickiego. Nowy naczelnik jednostki por. Giedroyć sporządził raport informujący, że Tarło-Maziński posiada uposażenie pieniężne radioszkoły (600 rubli), a także pieczęcie herbowe oddziału, którymi miał się nielegalnie posługiwać, ponadto miał przebywać w Mińsku na urlopie wojskowym bez zgody dowódcy ${ }^{17}$.

Poprowadzenia sprawy Tarły-Mazińskiego podjął się por. Witold Szulborski, prokurator sądu polowego w Bobrujsku, który postanowił przesłuchać ppor. Floriana Kotowicza, pomocnika zawiadowcy szkoły radiotelegraficznej, który został wysłany do Mińska z misją odzyskania uposażenia oraz pieczęci. Kotowicz zeznał, że Tarło-Maziński był dowódcą jednostki do 4 stycznia 1918 r. Następnie została powołana komisja przejęcia sum pieniężnych oraz inwentarza jednostki, na czele z chorążym Giedroyciem. Według Kotowicza komisja otrzymała od Tarły-Mazińskiego inwentarz oraz pieniądze w kwocie 18 tys. rubli. Następnie Tarło-Maziński przeformował jednostkę w szkołę radiotelegraficzną przy radiogrupie, która miała pozostać tymczasowo w Mińsku. Komisja miała zgodzić się na pozostawienie pieczątek herbowych oddziału oraz zaliczki 600 rubli u Tarły-Mazińskiego. 13 stycznia szkoła została wysłana do wsi Żerebce niedaleko Bobrujska, jednak Tarło-Maziński, wraz z częścią żołnierzy, pozostał w Mińsku' ${ }^{18}$.

19 stycznia Kotowicz otrzymał od Giedroycia polecenie udania się do Mińska i odebrania pieczęci oraz zaliczki od Tarły-Mazińskiego. Nie mógł jednak powrócić aż do 21 lutego ze względu na wzmożoną aktywność bolszewików. Kotowicz wraz z ppor. Tarłą-Mazińskim rozpoczął kompletowanie inwentarza dla szkoły radiotelegraficznej, następnie Tarło-Maziński miał udać się na sześciotygodniowy urlop, na który - jak utrzymywał

\footnotetext{
15 J. Dowbor-Muśnicki, Moje wspomnienia..., s. 330.

16 CAW-WBH, I Korpus Polski - Oddzielna Radiotelegraficzna Grupa, sygn. I.122.49.6, Zawiadomienie por. Giedroycia, 31 I 1918 r., b.p.

17 CAW-WBH, I Korpus Polski - Sztab Korpusu, sygn. I.122.1.34, Raport naczelnika Samodzielnej Radiotelegraficznej Grupy Polskiego Korpusu por. Giedroycia, 14 II 1918 r., k. 224.

18 Ibidem, Zeznanie podporucznika Floriana Kotowicza pełniącego obowiązki pomocnika zawiadowcy Szkoły Radiotelegraficznej1 Korpusu Polskiego, 26 II 1918 r., k. 231-232.
} 


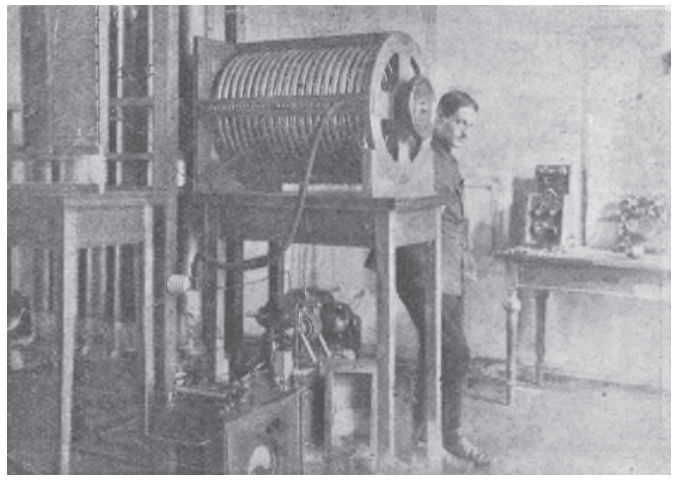

Aparatura nadawcza w radiostacji w Bobrujsku w roku 1918. Na fotografii dowódca korpusowego oddziału radiotelegraficznego kapitan Giedroyć.

Zdjęcie ilustrujące artykuł D. Macesowicza-

-Majewskiego, Łączność w 1 Korpusie Polskim, „Wiarus” 1937, nr 25

Kotowicz - nie dostał jednak zgody. Zamiast tego otrzymał wezwanie do przyjechania do Żerebców ${ }^{19}$.

Z zeznania Tarły-Mazińskiego, sporządzonego dla prokuratora Szulborskiego pod koniec lutego $1918 \mathrm{r}$. w Mińsku, wynika, że pełnił on obowiązki dowódcy radiotelegraficznego Korpusu do 15 stycznia 1918 r. Następnie mianowano go pomocnikiem nowego naczelnika por. Giedroycia, jednak jak sam przyznał, ze względów ambicjonalnych nie zgodził się na to i poprosił o skierowanie go na stanowisko naczelnika szkoły, jak też uczyniono.

Tarło-Maziński powtórzył wersję Kotowicza, podkreślając, że na to, aby zatrzymał pieczęcie herbowe oddziału, wyraził zgodę także Giedroyć, dlatego postawiony przez niego zarzut o przywłaszczenie pieczęci był zupełnie niezrozumiały ${ }^{20}$. Pieczęć postanowił złożyć zatem na ręce Szulborskiego. Twierdził ponadto, że przybycie do Bobrujska uniemożliwiło mu wystąpienie bolszewików w Mińsku, dlatego też postanowił pozostać z częścią komendy, która nie zdołała dotrzeć do twierdzy. Do Mińska pofatygował się sam Giedroyć, który miał jednak nie podejmować tematu pieczęci ani pieniędzy, a jedynie wręczyć mu bez słowa raport. Tarło-Maziński twierdził także, że nie złożył wniosku o urlop, a jego zwolnienie $\mathrm{z}$ wojska było fikcyjne ze względu na to, że obawiał się represji ze strony bolszewików w Mińsku; jak tłumaczył w liście do por. Szulborskiego: „Zwolniony byłem z wojska jak i wielu wojskowych Polskiego Korpusu fikcyjnie dla uniknięcia aresztowania przez bolszewików”21.

W wyniku raportu Giedroycia Tarło-Maziński został osadzony w areszcie decyzją komendanta miasta Mińsk, który wziął pod uwagę zarzut nieuprawnionego posługiwania się pieczęciami oddziału oraz przywłaszczenie 600 rubli, natomiast nie zagłębił się w kwestię oskarżeń o niewykonanie rozkazu stawienia

\footnotetext{
19 Ibidem, k. 232.
}

20 CAW-WBH, I Korpus Polski - Sztab Korpusu sygn. I.122.1.34, List Zygmunta Włodzimierza Tarły-Mazińskiego do prokuratora Sądu Korpusu Polskiego, [luty 1918 r.], k. 233.

${ }^{21} \quad$ Ibidem, k. 234. 
się $\mathrm{w}$ Bobrujsku ${ }^{22}$. Tarło-Maziński został ostatecznie uwolniony $\mathrm{z}$ aresztu decyzją Szulborskiego, który w raporcie do dowódcy I Korpusu Polskiego stwierdzil, że dochodzenie, którego się podjął: „nie potwierdziło raportu porucznika Giedroycia i przedstawiło sprawę $\mathrm{w}$ innym świetle"23. Pomimo to Giedroyć w marcu $1918 \mathrm{r}$. wykreślił go rozkazem z listy oficerów I Korpusu Polskiego z powodu dwumiesięcznej nieobecności w jednostce ${ }^{24}$.

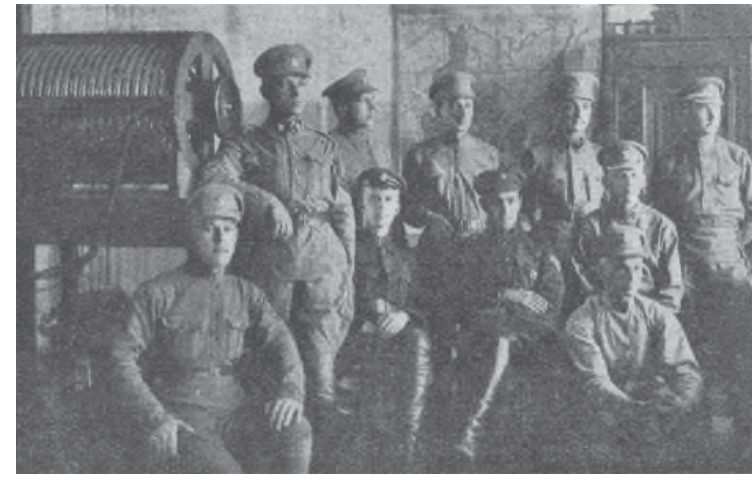

Personel głównej radiostacji I Polskiego Korpusu w Bobrujsku. Na fotografii por. Sroka (dowódca), pchor. Lewin-Lewiński, telegrafiści: Wasilewski, Wilczyński i Macesowicz-Majewski; mechanicy: Palczewski i Wójcik oraz uczniowie praktykanci. Zdjęcie ilustrujące artykuł D. Macesowicza-Majewskiego, Łączność w 1 Korpusie Polskim, „Wiarus” 1937, nr 25

Po powrocie do kraju w listopadzie 1918 r. Tarło-Maziński pozostawał szefem oddziału techniki wojskowej Sztabu Generalnego pod dowództwem gen. Edwarda Śmigłego Rydza w Lublinie do stycznia 1919 r. Następnie w 1920 r. zgłosił się ochotniczo do służby, pełniąc kolejno funkcje oficera łącznikowego i oficera inspektora robót fortyfikacyjnych w Warszawie. Przydzielono go także do zapasowego batalionu radiotelegraficznego. Sprawował również stanowisko kierownika Wydziału Informacyjnego Obywatelskiego Komitetu Wykonawczego Obrony Państwa w 1920 r. $^{25}$

Do sprawy jego zarzutów z czasów służby w I Korpusie powrócono dopiero przy okazji podania Tarły-Mazińskiego o przyjęcie go do Wojska Polskiego w charakterze oficera rezerwy ${ }^{26}$. Istotne w kontekście tej sprawy wydają się są słowa $\mathrm{z}$ końcowego memoriału sędziego sądu korpusowego

22 CAW-WBH, I Korpus Polski - Sztab Korpusu, sygn. I.122.1.34, Raport podporucznika prokuratora Szulborskiego do dowódcy I Polskiego Korpusu, 24 II 1918 r., k. 227.

23 Ibidem.

24 „Podporucznika Tarło-Mazińskiego [...] jako nieobecn[ego] Przeszło 2 miesiące, rozkazuję wykreślić z listy oficerskiej powierzonego mi oddziału”. CAW-WBH, I Korpus Polski - Oddzielna Radiotelegraficzna Grupa, sygn. I.122.49.42, Rozkaz nr 52 do Pierwszego Korpusowego Radiotelegraficznego Oddziału, 16 III 1918 r., b.p.

25 CAW-WBH, AP 1769/89/5221, Tarło-Maziński Zygmunt, Odpis. Ministerstwo Spraw Wojskowych. Inspektorat Generalny Armji Ochotniczej. Oddz. I Z. 402/I. Legitymacja, Warszawa 27 VII 1920 r., b.p.

26 Ibidem, Informacja o przekazaniu dokumentów Tarły-Mazińskiego Zygmunta Włodzimierza celem orzeczenia, czy może być oficerem WP, b.d., b.p. 
I Korpusu Edwarda Józefa Saskiego: „Pewna część przestępców pociągniętych do odpowiedzialności sądowej uchyliła się od wymiaru sprawiedliwości dezerterując, lub w inny sposób ukrywając się przed sądem lub wymiarem kary, co do innych wymiar kary został odłożony do czasu przejścia korpusu na stopę pokojową, Dobro społeczne - jak zaznaczył Saski - wymaga, aby ludzie występni ponieśli karę zasłużoną, usuwającą ich ze społeczeństwa"27.

We wrześniu $1921 \mathrm{r}$. Oficerski Trybunał Orzekający ${ }^{28}$ wszczął dochodzenie z powodu pisma z oskarżeniem, które złożył 1 grudnia 1919 r. były podwładny Tarły-Mazińskiego z I Korpusu Polskiego por. Janusz de Lewin

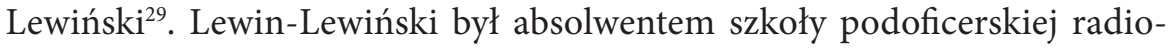
telegrafu w armii rosyjskiej, którą ukończył w 1916 r. Po demobilizacji z I Korpusu Polskiego w Wojsku Polskim pełnił funkcję dowódcy stacji radiotelegraficznych i awansował na stopień porucznika. Był dobrze ocenianym oficerem, a jedną z pochwał wystawił wspomniany już wcześniej Kotowicz, który w swojej opinii pisał o nim: „Doskonały materiał na oficera, bardzo dobrego służbistę, sumienny, taktowny energiczny”30.

Opinia na temat Tarły-Mazińskiego, którą przesłał do prokuratury Lewin-Lewiński, była druzgocąca. Twierdził, że: „Gdy bolszewicy zaczęli korpusowi zagrażać p. Tarło rozpoczął starania o zwolnienie go z wojska” - ponadto „Oficerowie, którzy chcieli nałożyć polski mundur, mieli to wzbronione, gdyż Tarło-Maziński zmuszony byłby zrobić to samo, lecz ze strachu przed bolszewikami, wolał chodzić w mundurze rosyjskim. Gdy bolszewicy zaczęli korpusowi zagrażać, rozpoczął on starania o zwolnienie go z wojska. W czasie zajęcia Mińska, gdy wszyscy Polacy chwycili broń przeciw bolszewikom, pana Tarło widziano rozbijającego się «swymi» końmi po ulicach miasta z kobietami. Po zdobyciu Mińska przez ludność polską p. Tarło wziął w posiadanie cały bogaty materiał telegraficzny wraz ze stacją radiotelegraficzną". Lewin-Lewiński kończył swą opinię oskarżeniami o kradzież koni, uprzęży, wozów, aparatów i przedmiotów zdobytych na bolszewikach w Mińsku, a także, co istotniejsze,

27 CAW-WBH, Sąd Korpusowy I Korpusu Polskiego, sygn. I.122.14.307, Memoriał sędziego sądu korpusowego I Korpusu Edwarda Józefa Saskiego, 2 VI 1918 r., b.p.

28 Ciało to zostało ustanowione dekretem Józefa Piłsudskiego z 25 IX 1919 r. do orzekania w sprawach, w których formułowano zarzuty o czyny nieetyczne popełnione przez oficerów w czasie służby przed wstąpieniem do Wojska Polskiego. Dekret Naczelnego Wodza Wojsk Polskich o ustaleniu Oficerskiego Trybunału Orzekającego z 25 IX 1919 r. (Dziennik Rozkazów Wojskowych z 1919 r., nr 93, poz. 3572).

29 CAW-WBH, AP 1769/89/5221, Tarło-Maziński Zygmunt, Pismo Szefa Wydziału Prawnego MSWojsk. gen. Jakuba Krzemieńskiego do Oficerskiego Trybunału Orzekającego w sprawie wdrożenia dochodzeń karnych przeciwko kapitanowi Włodzimierzowi Zygmuntowi Tarle-Mazińskiemu, 23 IX 1921 r., b.p.

30 CAW-WBH, AP 2846, Lewin-Lewiński Janusz, Karta kwalifikacyjna do Kom. Weryf. ppor. De Lewina-Lewińskiego Janusza, b.d., b.p. 
zarzutem o zdradę wojskową - zostawienie oddziału na łaskę losu i pozbawienie go koni w najkrytyczniejszej chwili31 .

Według obowiązującego w Polsce od 29 lipca 1919 r. wojskowego kodeksu karnego, opartego na przepisach wojskowych niemieckiego kodeksu wojskowego z 1872 r., dezerterem określało się osobę, która „samowolnie oddaliła [się] ze swego oddziału, opuściła swe stanowisko służbowe lub $\mathrm{z}$ umysłu z dala od tychże się trzymała" ${ }^{32}$. Według artykułu 71 za dezercję w warunkach mobilizacji kara mogła opiewać na wyrok od 5 do 10 lat więzienia $^{33}$.

Inną obciążającą Tarłę-Mazińskiego opinią było orzeczenie z 1 grudnia 1919 r. znanego już nam Kotowicza, który stwierdził, że Tarło-Maziński jako dowódca oddziału radiotelegraficznego nie był lubiany przez oficerów przez swoją niegospodarność oraz tchórzostwo: „W okresie walk Korpusu z bolszewikami podporucznik Tarło Maziński, nie chcąc narażać się, puścił swój oddział udający się do Bobrujska i pozostał w Mińsku”. Kotowicz poruszył także sprawę przywłaszczenia sprzętu radiotelegraficznego. Pisał, że Tarło-Maziński wywiózł go przed wkroczeniem Niemców do Mińska i utrzymywał, że przyrządy te odda I Korpusowi Polskiemu bądź też weźmie na przechowanie dla Politechniki Warszawskiej. W rzeczywistości jednak Korpus otrzymał nieznaczną część tych sprzętów. Dodatkowo Kotowicz stwierdził, że Tarło-Maziński nieprawomocnie używał tytułu inżyniera: „o ile wiem, nie należy mu się, ponieważ nie ukończył wyższej uczelni technicznej”34. Jak warto zauważyć, opinia Kotowicza, która w 1918 r. najprawdopodobniej zaważyła na decyzji uniewinnienia Mazińskiego, tym razem uległa radykalnej zmianie. Wynika to z faktu, że w kwietniu 1918 r., a więc już po uniewinnieniu Tarła-Mazińskiego przez prokuratora Szulborskiego, por. Giedroyć oddelegował Kotowicza powtórnie wraz z Lewinem-Lewińskim do Mińska w celu odzyskania: „od porucznika Tarło-Mazińskiego rzeczy zabranych w zarządzie i warsztatach radiotelegraficznych Zachodniego Frontu, wśród których są stacje awiacyjne, telefony, detektory, [...] instrukcje itp. niezbędnie nam potrzebne" 35 .

31 CAW-WBH, AP 1769/89/5221, Tarło-Maziński Zygmunt, Opinja ppor. Janusza de Lewin-Lewińskiego, dowódcy pol. stacji dt. Nr. 1 Polskich, 1 XII 1919 r., k. 17.

32 Rozdział III: „Samowolne oddalenie się i dezercja”, \$ 64, Kodeks karny wojskowy: $z$ dodaniem ustaw i przepisów wprowadczych, przechodnich i uzupetniajacych oraz komentarza, red. W. Makowski, Warszawa 1920, s. 251.

33 Rozdział III: „Samowolne oddalenie się i dezercja”, \$ 71, Kodeks karny..., s. 270-271.

34 CAW-WBH, AP 1769/89/5221, Tarło-Maziński Zygmunt, Odpis protokołu orzeczenia por. Kotowicza Florjana, Dowódcy Bataljonu Radjotelegraficznego WP, 1 XII 1919 r., k. 13.

35 CAW-WBH, I Korpus Polski - Oddzielna Radiotelegraficzna Grupa, sygn. I.122.49.6, Do Szefa Sztabu Korpusu - podpisane prze dowódcę oddziału porucznika Giedroycia, [kwiecień 1918], b.p. 
Pejoratywny obraz działalności Tarły-Mazińskiego w I Korpusie Polskim przedstawił również jego ówczesny podwładny ppor. Witold Małujło. Stwierdził, że pomimo tego, iż służył pod komendą Tarły-Mazińskiego w oddziale, nie poznał go bliżej z powodu odbywania częstych podróży służbowych. Kiedy powrócił na stałe do jednostki w lutym 1918 r., dowiedział się, że Tarło-Maziński: „nie przybył z oddziałem do Bobrujska, nie chcąc narażać się bolszewikom. Zarzucano mu wówczas tchórzostwo oraz przywłaszczenie sumy 2000 rubli, którą otrzymał na prowadzenie szkoły radiotelegraficznej”. Małujło był przekonany, że Tarło-Maziński otrzymał tę sumę na cele szkoły radiotelegraficznej, ponieważ brał udział w pracach komisji rewizyjnej oddziału ${ }^{36}$.

Kolejnym, stawiającym byłego dowódcę w złym świetle, było lakoniczne świadectwo ppor. Hugona Zaremby, który stwierdził, że: „Ze względu na działalność ppor. Tarło-Mazińskiego w I Korpusie Polskim, podczas której często nadużywał swej władzy w bardzo poważnym stopniu, uważam go za człowieka kategorycznie niezasługującego na szacunek i poważanie. Nie mam również zaufania do uczciwości p. T[arły-]M[azińskiego]. Osobiście zostałem przez niego poszkodowany na parę tysięcy marek" ${ }^{37}$.

Niepochlebną opinię napisał także por. Łącki, zastępca Tarły-Mazińskiego, który stwierdził, że był on „oportunistą", który: „nawet najdrobniejszy szczegół lub pozór potrafi wykorzystać na swoją korzyść. [...] pomimo tego, że był faktycznie zwolniony z I Korpusu, nosił mundur i występował jako oficer w tych wypadkach, kiedy to dla niego było wygodne". Łącki stwierdził ponadto, że: ,jako oficer bojowy [...] nie przedstawia żadnej wartości, gdyż jest bezwzględnie tchórzowatego usposobienia i jako taki do wojska nie nadaje się w żadnym razie" 38 .

Obciążające zeznania względem Tarły-Mazińskiego złożył przed Oficerskim Trybunałem Orzekającym także były członek I Korpusu Polskiego - por. Antoni Stalewski. Stwierdził w nich, że „Tarło-Maziński chodził zawsze w mundurze oficera rosyjskiego, wtenczas gdy wszyscy oficerowie I Korp[usu] nosili mundury oficera polskiego - względnie na czapkach mieli orzełki". Ponadto Stalewski zeznał w kwestii zarzutów o kradzież sprzętu, że Tarło-Maziński przywłaszczył ze stacji radiotelegraficznej

36 CAW-WBH, AP 1769/89/5221, Tarło-Maziński Zygmunt, Odpis protokołu orzeczenia ppor. Witolda Małujły, Dowódcy Kompanji Szkolenja I Baonu Radjotelegraficznego, 1 XII 1919 r., k. $13 \mathrm{v}$.

37 Ibidem, Odpis protokołu orzeczenia ppor. Hugona Zaremby, Oficera kasowego I Baonu Radjotelegraficznego, 1 XII 1919 r., k. 13v., 14.

38 Ibidem, Opinja por. Łąckiego o P. Tarle-Mazińskim i jego działalności w I-szym Polskim korpusie, 10 XII 1919 r., k. 52. 


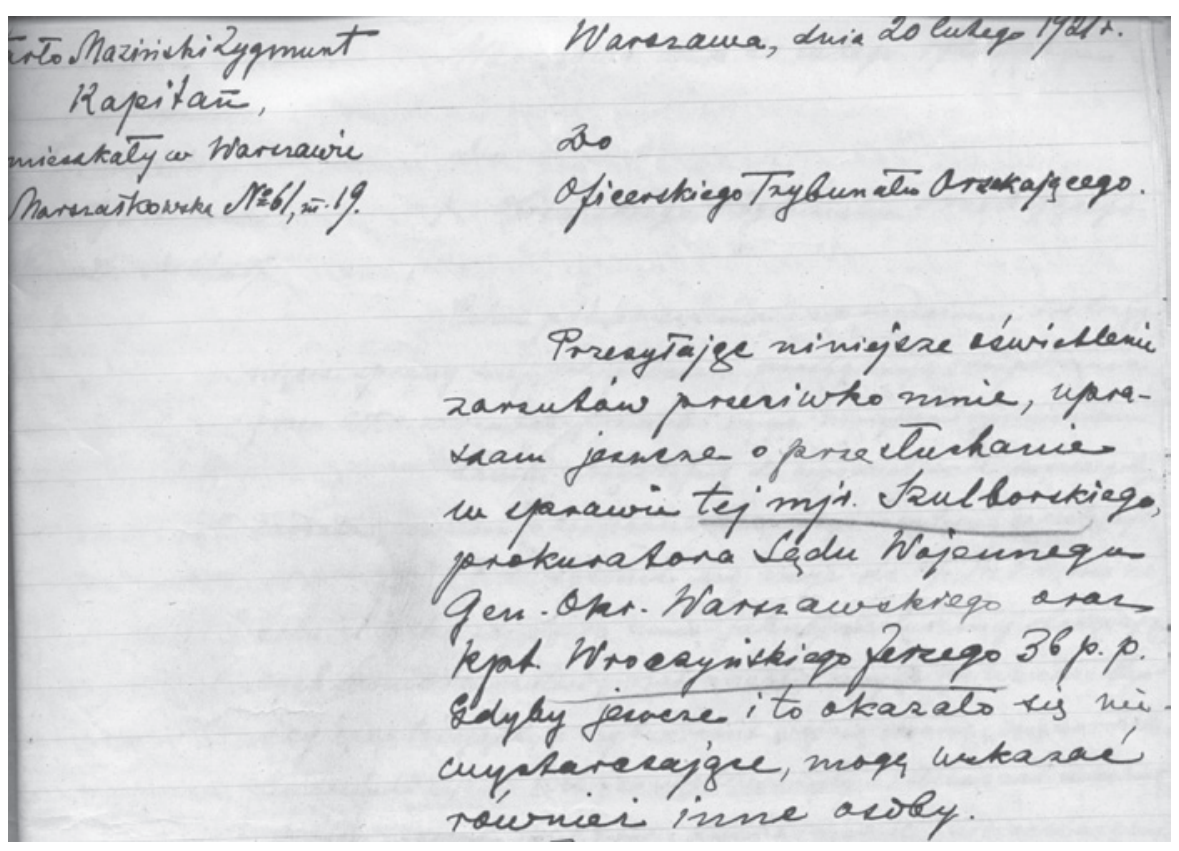

Fragment Listu Zygmunta Tarły-Mazińskiego do Oficerskiego Oddziału Orzekającego z 20 lutego 1920 r. CAW-WBH, AP 1769/89/5221, Tarło-Maziński Zygmunt

przywiezionej przez Stablewskiego z Petersburga lornetkę i latarkę z akumulatorami ${ }^{39}$.

Były to bardzo poważne zarzuty czynnych oficerów Wojska Polskiego. Tarło-Maziński ustosunkował się do nich w wyczerpującym liście do Oficerskiego Trybunału Orzekającego, rozpoczynając od zdania: „Wszyscy oskarżający mnie przy spotkaniu się ze mną, nie wiedząc oczywiście, że wiadome mi są ich opinie o mnie, odnosili i odnoszą się do mnie bardzo dobrze, niektórzy nawet po koleżeńsku wprost na "wy»" ${ }^{40}$. Uważał, że od stawianych zarzutów w pełni mógłby go oczyścić jedynie jego bezpośredni ówczesny zwierzchnik gen. Władimir Agapiejew ${ }^{41}$, szef sztabu I Korpusu

39 Ibidem, Protokół przesłuchania por. Antoniego Stalewskiego przez Oficerski Trybunał Orzekający w sprawie przeciwko b. kpt. Tarle-Mazińskiemu, 2 VIII 1921 r., k. 19.

40 Ibidem, List kapitana Zygmunta Tarły-Mazińskiego do Oficerskiego Trybunału Orzekającego, 20 II 1921 r., b.p.

41 Władimir Pietrowicz Agapiejew, ros. Владимир Петрович Агапеев (ur. 1876 - zm. 1956) generał lejtnant Armii Imperium Rosyjskiego. Uczestnik wojny rosyjsko-japońskiej. W latach 1907-1909 attaché wojskowy w królestwach Serbii, Belgii oraz Holandii. W 1917 r. został szefem sztabu I Korpusu Polskiego w Rosji. W maju 1918 r. wstąpił do armii białych gen. Antona I. Denikina. S.Y. Nechaev, Русские в Латинской Америке, Moskwa 2010, s. 293. 
Polskiego, który przebywał poza terytorium Polski. Według Tarły-Mazińskiego to właśnie od niego miał otrzymać ściśle tajne polecenie pozostania z częścią oddziału w Mińsku wraz z zaświadczeniem zwolnienia z wojska $\mathrm{w}$ celu zatajenia tego faktu przed bolszewikami. Tarło-Maziński bronił się argumentem, że: „W Mińsku oprócz niego pozostało b[ardzo] dużo oficerów korpusu" (wymienił nazwisko mjr. Ignacego Matuszewskiego z II Oddziału Naczelnego Dowództwa oraz co ciekawe samego prokuratora mjr. Szulborskiego, żaląc się, że do nich nikt o to „pretensji nie rości”).

Odpowiadając na zarzuty Kotowicza, pisał, że niebezpieczeństwo groziło bardziej tym, którzy pozostali w Mińsku, niż tym, którzy udali się do Bobrujska. „Nie mogę tu nie zaznaczyć, że inni oficerowie naprzeciw z por. Giedroyciem, właśnie w czasie tym, kiedy Niemcy zagrażali korpusowi, wyjechali do Bobrujska i nikt im nawet i wówczas nie zarzucał przynajmniej pisemnie, tchórzostwa. [...] Odpowiedzialność za to spoczywa całkowicie na por. Giedroyciu, który przyjechawszy do Bobrujska zamiast zająć [się] przetransportowaniem zdobytego materjału, rozpoczął intrygi przeciwko mnie. Wiedział również o tem bardzo dobrze kpt. Kotowicz, który przecież cały czas był ze mną w Mińsku" ${ }^{\prime 2}$. Sam por. Giedroyć nie mógł odnieść się do zarzutów, ponieważ poległ na polu walki w 1919 r. ${ }^{43}$ Tarło-Maziński uważał, że to właśnie on zapoczątkował intrygę w grudniu 1917 r. Miała ona doprowadzić do objęcia przez Giedroycia dowództwa nad oddziałem radiotelegraficznym i wykluczeniem konkurencji w postaci Tarły-Mazińskiego: „por. Giedroyć - pisał - zamiast wysłać ludzi do objęcia materjału radiotelegraficznego, przyjechał po paru dniach do Mińska sam, widział się ze mną, nie powiedział ani słowa o wyliczeniu się z owych 2000 rubli, lecz złożył meldunek do komendy miasta, w którym zaznaczył, że ja przywłaszczyłem sobie z sum korpusu 2000 rubli i prosił o aresztowanie mnie". Tarło-Maziński twierdził, że pieniądze te zostały mu przekazane od komisji oddziału, ponadto utrzymywał, że nie tylko nie zawłaszczył 2000 rubli, lecz przy zamykaniu rachunków oddziału powinno mu zostać zwróconych ok. 3000 rubli. Co zaś się tyczyło sprzętu radiotelegraficznego, to kategorycznie stwierdził, że cała wina za jego pozostawienie w Mińsku spoczywała również na por. Giedroyciu, który: „przyjechawszy do Mińska, zamiast zająć się przetransportowaniem zdobytego materjału, rozpoczął intrygi”.

Odnosząc się lakonicznie do zeznań pozostałych swoich podwładnych, pisał, że por. Lewina-Lewińskiego należałoby oddać pod nadzór lekarski ze względu na jego „chorą wyobraźnię”. Utrzymywał przy tym, że gdyby we wszystkich jego zarzutach była chociaż odrobina prawdy, to jest rzeczą

42 CAW-WBH, AP 1769/89/5221, Tarło-Maziński Zygmunt, List kapitana Zygmunta Tarły-Mazińskiego do Oficerskiego Trybunału Orzekającego, 20 II 1921 r., b.p.

43 D. Macesowicz-Majewski, Łączność w 1 Korpusie Polskim, „Wiarus” 1937, nr 25, s. 605. 
jasną, że prokurator postawiłby go pod sąd dowództwa korpusu: „Widząc jednak bezpodstawność tych zarzutów, nie przypisywał do nich większej wagi”. Tarło-Maziński orzekł ponadto, że: „opinja ppor. Lewińskiego, który w czasach owych był sierżantem i jako żołnierz najzupełniej nie orientował się w sytuacji, jest niepoważna, chaotyczna i fantastyczna [...], że nie wymaga prawie żadnych komentarzy". Do zeznania por. Łąckiego w ogóle się nie odniósł, stwierdzając: „że jest tego rodzaju, iż wydaje mu się, że żadnych wyjaśnień nie wymaga, ponieważ mówi sama za siebie”. Zarzucił mu za to, że $\mathrm{w}$ czasie wojny z bolszewikami w $1920 \mathrm{r}$. Łącki pod pozorem materiału technicznego wysłał wagon soli ku liniom czołowym celem sprzedania go, a cała ta sprawa została zamieciona pod dywan.

$\mathrm{Na}$ temat por. Hugona Zaremby Tarło-Maziński napisał, że w Mińsku przyjął go do swojego oddziału jedynie z litości, ponieważ położenie jego było zupełnie bez wyjścia: „Po przebyciu w oddziale około $10 \mathrm{dni}$ poprosił mię o urlop do Petersburga, a uzyskawszy takowy, wyjechał i odtąd go więcej w oddziale nie widziałem. Jakim więc prawem śmiał napisać, iż «uważa mnie za człowieka niezasługującego na szacunek i poważanie, ponieważ często nadużywałem swej władzy w bardzo poważnym stopniu»!"44

W kwestii zarzutów por. Lewina-Lewińskiego Tarło-Maziński złożył jeszcze jedno wyczerpujące wyjaśnienie w formie bezpośredniego zeznania przed prokuraturą przy Wojskowym Sądzie Okręgowym nr $1 \mathrm{w}$ Warszawie 13 grudnia 1920 r., w którym powtórzył w zasadzie wszystkie tezy z listu z 20 lutego 1920 r. Twierdził, że nie jest winien kradzieży koni, które zwrócił prawowitym właścicielom, ani tym bardziej zarzutu przywłaszczenia sprzętu, który w większości przechwycili Niemcy po zajęciu Mińska. Uparcie zeznawał również, że nie zostawił oddziału na „łaskę losu”, ponieważ wówczas już nim nie dowodził, a więc nie był za niego odpowiedzialny ${ }^{45}$.

W aktach prokuratury nie zabrakło także pozytywnych głosów o Tarle-Mazińskim - jednym z nich było zeznanie z 15 listopada 1919 r. ówcześnie pełniącego obowiązki szefa Sztabu Generalnego Inspektora Artylerii kpt. Leona Wiszniowskiego, który znał go z okresu służby w I Korpusie Polskim. Jak zeznawał: „Poznałem go na posiedzeniu kilku oficerów Polaków z b[yłej] armji rosyjskiej, które miało na celu zorganizowanie Związku Wojskowych Polaków [...] Porucznik Maziński był na wszystkich posiedzeniach

44 Ibidem, List kapitana Zygmunta Tarły-Mazińskiego do Oficerskiego Trybunału Orzekającego, 20 II 1921 r., b.p.

45 Ibidem, Protokół badania obwinionego Zygmunta Tarły-Mazińskiego spisany w Prokuraturze przy Wojskowym Sądzie Okręgowym nr 1 w Warszawie, 13 XII 1920 r., b.p. 
tego kółka (9 oficerów) zawsze zapalczywie oddany sprawie polskiej i tworzeniu wojska polskiego na Kresach"46.

Pozytywną opinię, nieodnoszącą się jednak do sprawy jego kontrowersyjnej działalności w I Korpusie Polskim, wydał także Generalny Inspektor Wojsk Techniczych przy Naczelnym Dowództwie gen. Władysław Wejtko, pisząc: „Świadczę, że osobiście mi znany kpt. Tarło jest fachowym technikiem i przyniesie korzyść w odpowiednim urzędzie w saperach, a zwłaszcza w obecnej chwili" [lipiec 1920 - przyp. aut.] ${ }^{47}$.

W osobnym liście z 20 lutego 1921 r., również zaadresowanym do Oficerskiego Trybunału Orzekającego, Tarło-Maziński przedstawił opinię na swój temat sporządzoną przez prokuratora Szulborskiego, który stwierdził, że: „Kpt. Maziński jako Polak i jako oficer cieszy się jego jak najlepszą opinią". - dowodzić miał tego fakt, że - „Jest wybitnym znawcą radiotelegrafu, który oddał całą swą wiedzę na usługi tworzących się w Rosji Wojsk Polskich". Szulborski w swoim orzeczeniu nie odniósł się choćby słowem na temat zarzutów, które ciążyły na Tarle-Mazińskim ${ }^{48}$.

Tarło-Maziński przedstawił na swoją obronę także świadectwo swojego podwładnego z czasów dowodzenia oddziałem kpt. Jerzego Wroczyńskiego, który twierdził, że opieszałość Tarły-Mazińskiego w opuszczeniu Mińska wynikała jedynie z zerwania łączności z Bobrujskiem z powodu działalności bolszewików. Pomimo tego miał on pomagać żołnierzom udającym się do twierdzy, wystawiając im podrabiane dokumenty za pomocą pieczątki herbowej. Wroczyński pisał, że w czasie walk o Bobrujsk Tarło-Maziński miał rozbroić oddział bolszewików mieszczący się w tym samym gmachu, w którym poprzednio mieściła się jednostka radiotelegraficzna. Wroczyński twierdził, że nieprawdą jest, jakoby Tarło-Maziński pozostawił swoich podkomendnych na łaskę losu. Wręcz przeciwnie - zorganizował im przerzut koleją z Mińska do Bobrujska: „wiadomo mi, że wysłaniem swego oddziału z Mińska do Bobrujska kpt. Maziński osobiście się zajmował, wykorzystując znajomości swoje w zarządzie kolejowym”. Wroczyński stwierdził ponadto, że Tarło-Maziński był bardzo dobrym organizatorem i żadnych przyczyn

${ }^{46}$ Ibidem, Protokół spisany z p.o. szefem Sztabu Gen. insp. art. kapitanem Leopoldem Wiszniowskim w sprawie wywiadu co do osoby i działalności pana Mazińskiego w czasie jego służby w b. I Korpusie generała Dowbora-Muśnickiego, 15 XI 1919 r., k. 29.

47 Ibidem, Świadectwo Generalnego Inspektora Wojsk Techniczych przy Naczelnym Dowództwie gen. Władysława Wejtko nt. kpt. Włodzimierza Tarły-Mazińskiego, 7 VII 1920 r., k. 66 .

48 Ibidem, Odpis wyciągu z zeznania ppłk. Szulborskiego dla prokuratora Najwyższego Sądu Wojskowego w sprawie kpt. Tarły-Mazińskiego [Tajne] do Oficerskiego Trybunału Orzekającego, 8 VIII 1921 r., b.p. 
do posądzania go o tchórzostwo nie znał. Oświadczył, że był on w zatargach z Giedroyciem, nie znał jednak ich powodów ${ }^{49}$.

Tarło-Maziński przytoczył także swoją prywatną korespondencję $\mathrm{z}$ Kotowiczem z 27 kwietnia 1918 r., najpewniej w celu zdyskredytowania go jako świadka. W liście tym Kotowicz w niezbyt przychylny sposób wypowiadał się na temat nowego naczelnika por. Giedroycia, którego nazwał „szkodliwym degeneratem" i chciał uzyskać od Tarły-Mazińskiego informacje dotyczące jego wykształcenia w dziedzinie radiotelegrafii, które poddawał w wątpliwość: „Prosiłbym bardzo Panu [sobie] przypomnieć - kiedy mianowicie porucznik Giedroyć został przydelegowany do radjogrupy, czy skończył szkołę przy radjogrupie, czy był w radjo rosyjskim - bo degenerata ten boi się ogromnie mnie i podał informacje o sobie niedokładne" ${ }^{50}$.

Sprawę Tarły-Mazińskiego Oficerski Trybunał Orzekający (OTO) zdecydował się przekazać prokuratorowi wojskowemu do „dalszego urzędowania" 26 września z $1921 \mathrm{r}^{51}$ Prokuratura skupiła się przede wszystkim na zarzucie przywłaszczenia majątku. Tarle-Mazińskiemu zdecydowano się postawić zarzut z artykułu 574 kodeksu karnego, który głosił, że: „winny przywłaszczenia mienia ruchomego ulegnie karze więzienia na czas od trzech

49 Ibidem, Protokół administracyjny spisany w sądzie w Lublinie przez kpt. Horodyskiego z kpt. Jerzym Wroczyńskim z 34 pp w sprawie zarzutów stawianych kpt. Tarle-Mazińskiemu, 11 IX 1921 r., k. 9-11.

50 Ibidem, Odpis listu ppor. (obecnie kpt.) Kotowicza adresowany do Tarły-Mazińskiego, 27 IV 1918 r., k. 95.

51 Ibidem, Pismo OTO do Oddziału V Sztabu Generalnego - Wydział III, 26 IX 1921 r., b.p. 
miesięcy do jednego roku" ${ }^{52}$. Udało mu się jednak uniknąć kary dzięki amnestii z 1923 r. ${ }^{53}$ i sprawę ostatecznie umorzył Wydział VIII Karny Sądu Okręgowego w Warszawie 24 listopada $1923 \mathrm{r}^{54}$

27 kwietnia 1925 r. kwestią weryfikacji Tarły-Mazińskego jako oficera Wojska Polskiego powtórnie zajął się Oficerski Trybunał Orzekający. We wrześniu 1925 r. na prośbę tej instytucji ${ }^{55}$ płk. Eugeniusz Szpręglewski zaopiniował służbę Tarły-Mazińskiego w I Korpusie Polskim w Rosji. Stwierdził, że: „miał w I-szym Polskim Korpusie opinję bardzo dobrego oficera i zdolnego fachowca radio-telegrafisty. [...] uważałem p[ana] Tarło-Mazińskiego za człowieka b[ardzo] uczciwego i oddanego całkowicie sprawie polskiej i b[ardzo] obowiązkowego w stosunkach służbowych" 56 .

Co ciekawe, o podobną opinię 20 sierpnia 1925 r. Trybunał zgłosił się również do dowódcy I Korpusu Polskiego gen. Dowbora-Muśnickiego. Najprawdopodobniej nie doczekano się jednak odpowiedzi bądź też list ten nie zachował się $e^{57}$. Jak świadczy jednak przytoczony wcześniej fragment wspomnień generała, potwierdzał on raczej wersję adwersarzy Tarły-Mazińskiego.

Niestety, dalsze akta z dochodzenia Oficerskiego Trybunału Orzekającego, wraz jego z końcową decyzją, nie zachowały się. Co ciekawe, jeszcze w $1937 \mathrm{r}$. w piśmie wojskowym „Wiarus”, w numerze poświęconym wojskom łączności, znalazły się wspomnienia członka I Korpusu Dionizego Macesowicza-Majewskiego, który również dał świadectwo tego, że Tarło-Maziński opuścił oddział w Mińsku wraz z rozpoczęciem walk z bolszewikami ${ }^{58}$.

W latach 1919-1923 Tarło-Maziński sprawował stanowisko inspektora szkolnego okręgu białostockiego. W 1925 r. rozpoczął pracę w warszawskich gimnazjach. W 1928 r. założył Liceum Przemysłowo-Techniczne Żeńskie

52 Kodeks karny obowiazujący tymczasowo w Rzeczypospolitej Polskiej na ziemiach b. zaboru rosyjskiego, t. 3, cz. XX-XXXVII, red. W. Makowski, Warszawa 1922, s. 307-308.

53 Ustawa z 6 VII 1923 r. w przedmiocie amnestji z powodu uznania granic Rzeczypospolitej, (Dz. U. z 1923 r., nr 70 poz. 555).

${ }^{54}$ CAW-WBH, AP 1769/89/5221, Tarło-Maziński Zygmunt, Decyzja Wydziału VIII Sądu Okręgowego w Warszawie ws. Zygmunta Tarły Mazińskiego, 24 XI 1923 r., k. 2-3.

55 Ibidem, Pismo OTO do Pana Pułkownika Eugenjusza Szpręglewskiego, 20 VIII 1925 r., b.p.

56 Ibidem, List Pułkownika Eugenjusza Szpręglewskiego do Przewodniczącego OTO, 19 IX 1925 r., b.p.

57 Ibidem, Pismo OTO do J.W. Pana Generała Dowbora-Muśnickiego Józefa, 20 VIII 1925 r., b.p.

58 Jak pisał Macesowicz-Majewski: „Na miejsce porucznika Tarło-Mazińskiego, który opuścił oddział jeszcze w Mińsku z rozpoczęciem walk z bolszewikami, został wyznaczony ś. p. kapitan Włodzimierz Giedroyć, który poległ na polu chwały w roku 1919 w wojsku polskim”. D. Macesowicz-Majewski, Łączność w 1 Korpusie Polskim..., s. 605. 


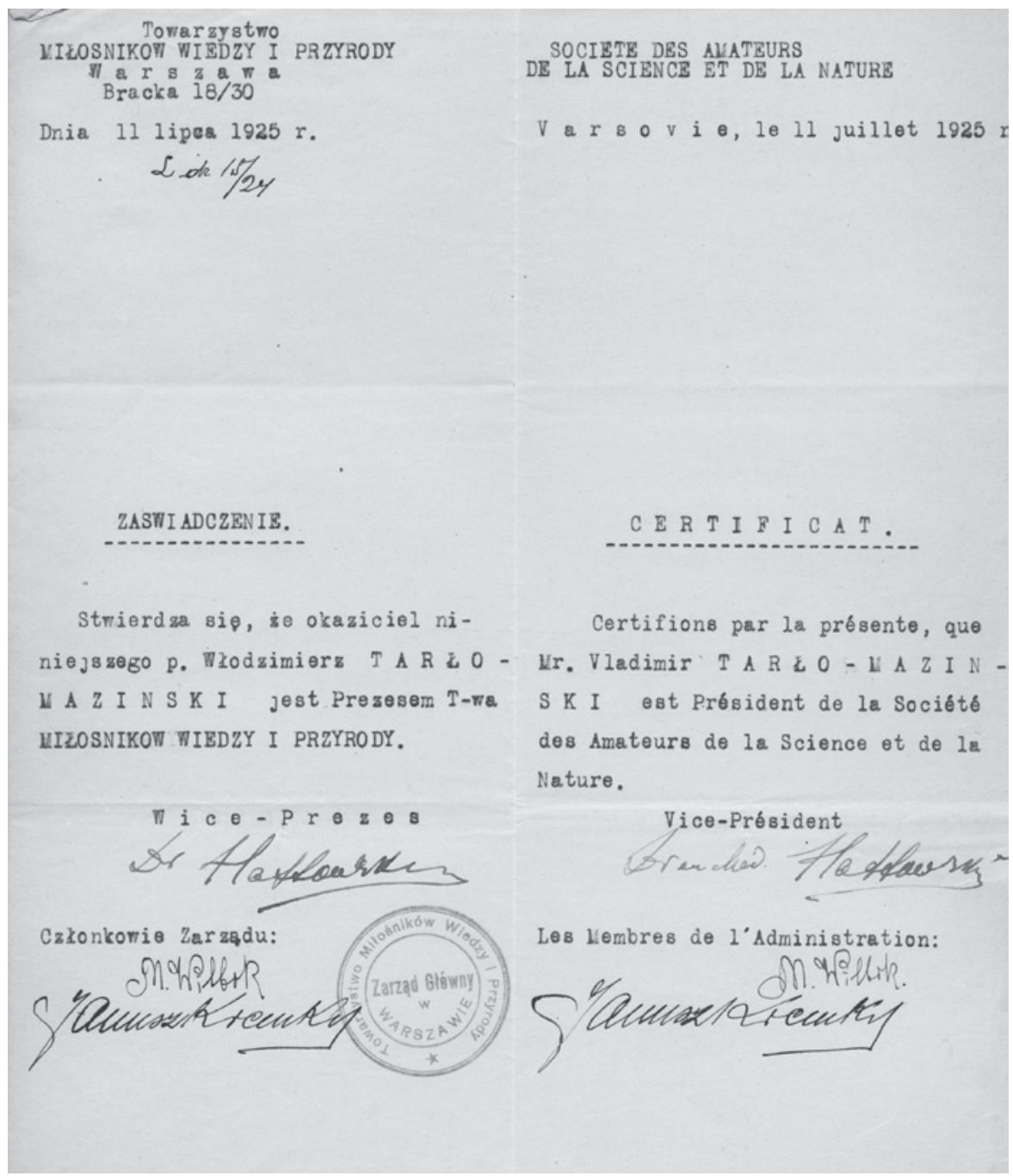

Zaświadczenie o zajmowaniu przez Zygmunta Włodzimierza Tarłę-Mazińskiego funkcji prezesa Towarzystwa Miłośników Wiedzy i Przyrody. CAW-WBH, AP 1769/89/5221, Tarło Maziński Zygmunt

Towarzystwa Szkół Pracy Twórczej, w którym był dyrektorem ${ }^{59}$. Tarło-Maziński był także prezesem zarejestrowanego w 1924 r. Polskiego Związku Synarchicznego, który cztery lata później zmienił nazwę na Związek Synarchiczny i działał nieprzerwanie, aż do $1939 \mathrm{r}^{60}$ Tarło-Maziński był także prezesem

59 T. Krok, Antymasońska komórka episkopatu Polski (1946-1952), Łomianki 2018, s. 252.

60 Synarchiści wyznawali poglądy głoszące, iż ustrojem najlepszym dla państwa byłaby swoista synteza ideologii liberalnych, czyli swobodnego rozwoju indywidualnego jednostek oraz 
Towarzystwa Miłośników Wiedzy i Przyrody założonego w 1936 r., które było polską ekspozyturą amerykańskiej paramasońskiej organizacji The Ancient Mystical Order Rosae Crucis ${ }^{61}$.

We wrześniu 1939 r. Tarło-Maziński wziął udział w kampanii polskiej i jako oficer Wojska Polskiego po klęsce ewakuował się ze sztabem do Rumunii, gdzie zrzucił mundur, aby uniknąć internowania. Następnie udało mu się przebić do Francji, gdzie zgłosił się do gen. Władysława Sikorskiego, który nie skorzystał $\mathrm{z}$ ofiarowanych przez niego „usług"62. We Francji Tarło-Maziński pracował jako nauczyciel w liceum polskim w Villard-de- Lans $^{63}$. Co istotne, znalazł się w dwuosobowym gronie, które

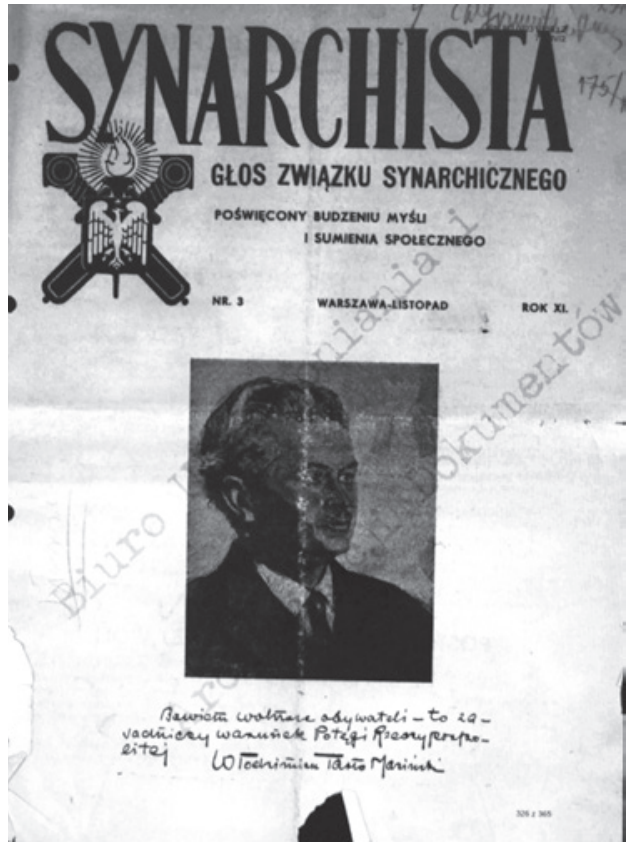

Okładka pisma „Synarchista” z portretem Zygmunta Włodzimierza Tarły-Mazińskiego, IPN BU 00231.119.2 po ujawnieniu zbrodni katyńskiej podejmowało próby kolaboracji z Niemcami. Wraz z Wincentym Jastrzębskim, wiceministrem skarbu w latach 1930-1934, zgłosił się do ambasady Rzeszy w Paryżu z propozycją założenia Komitetu Narodowego, który we

\footnotetext{
prawicowych zasad jedności państwa i silnych rządów. Połączone w ten sposób idee składały się właśnie na ustrój synarchiczny. W praktyce jego uosobieniem miałby być synarcha - czyli posiadacz pełnej władzy zwierzchniej. Prekursorem synarchizmu wywodzącego się pierwotnie $\mathrm{z}$ francuskich środowisk okultystycznych był filozof, propagator i tłumacz mesjanisty Józefa Marii Hoene-Wrońskiego - Józef Jankowski. Zob. P. Tomaszewski, Działalność i ideologia Związku Synarchicznego w latach 1924-1939 [w:] Historia i Polityka, t. 4, red. H. Stys, Toruń 2006, s. 226.

61 AMORC, czyli „The Ancient Mystical Order Rosae Crucis”, organizacja sięgająca historią 1916 r., związana z postacią Harveya Spencera Lewisa, za którego sprawą zakon ten wyodrębnił się z masonerii okultystycznej Rytu Memphis-Misraim, pociągając za sobą część z jego zwolenników. Podobnie jak wolnomularstwo, organizacja ta posiadała system hierarchiczny złożony ze stopni wtajemniczenia. Działalność adeptów AMORC polegała na duchowym samorozwoju i studiowaniu okultystycznych rękopisów. Zob. M. Introvigne, Rosicrucianism III: 19th-20th century [w:] Dictionary of Gnosis \& Western Esotericism, red. W. J. Hanegraaff, Leiden-Boston 2006, s. 1019-1020.

62 T. Krok, Antymasońska komórka...., s. 254.

63 T. Łepkowski, Wolna szkoła polska w okupowanej Francji. Historia Gimnazjum i Liceum im. Cypriana Norwida w Villard-de-Lans 1940-1946, Warszawa 1990, s. 46, 62.
} 
współpracy z Niemcami utworzyłby rząd w okupowanej Polsce ${ }^{64}$. Do Polski z powrotem ściągnął go w 1945 r. przedstawiciel PKWN Stefan Jędrychowski65. Po powrocie został naczelnikiem wydziału spraw konsularnych w Ministerstwie Spraw Zagranicznych i prezesem Komitetu Opieki nad Polakami za Granicą z ramienia Stronnictwa Demokratycznego ${ }^{66}$. Jako osoba zbliżona do kręgów wolnomularstwa i ezoteryki ${ }^{67}$ został po wojnie zwerbowany w charakterze tajnego współpracownika Ministerstwa Bezpieczeństwa $\mathrm{Pu}-$ blicznego i pod pseudonimem „Borowik” wykorzystywano go do rozpracowania polskich środowisk masońskich i okultystycznych ${ }^{68}$.

Tarło-Maziński zmarł w Warszawie 1 czerwca 1967 r. i został pochowany na Cmentarzu Wojskowym na Powązkach w kwaterze Dowborczyków.

\section{Bibliografia}

\section{Archiwalia}

Centralne Archiwum Wojskowe Wojskowego Biura Historycznego

Akta Personalno-Odznaczeniowe Tarło-Maziński Zygmunt

Akta Personalno-Odznaczeniowe Lewin-Lewiński Janusz

I Korpus Polski - Oddzielna Radiotelegraficzna Grupa

I Korpus Polski - Sztab Korpusu

Sąd Korpusowy I Korpusu Polskiego

Archiwum Instytutu Pamięci Narodowej

Teczka pracy Tajnego Współpracownika „Stanisław Pielewski”

\section{Akty prawne}

Dekret Naczelnego Wodza Wojsk Polskich o ustaleniu Oficerskiego Trybunału Orzekającego z dn. 25 IX 1919 r., (Dziennik Rozkazów Wojskowych z 1919 r., nr 93, poz. 3572).

64 D. Irving, Wypadek. Śmierć generała Sikorskiego, Pruszków 2000, s. 52, 282; W. H. Woods, Poland: Eagle in the East: A surveyof modern times, Nowy Jork 1968, s. 18.

65 Archiwum Instytutu Pamięci Narodowej, Teczka pracy Tajnego Wspołpracownika „Stanisław Pielewski”, sygn. BU 00170/917/3, Notatka. Tarło-Maziński Włodzimierz, 15 IV 1949 r., k. 18.

66 P. Tomaszewski, Działalność i ideologia..., s. 227.

67 Jak pisał o Tarle-Mazińskim Ludwik Hass w swoim słowniku biograficznym wolnomularzy polskich: „Intensywnie udzielał się w organizacjach przeplatających się ze sobą ponadnarodowych ruchów: ezoterycznego, mesjanistycznego i okultystycznego [...]. Pod koniec 1939 należał w stopniu mistrza do loży «Pythagore» (miejscowość i podporządkowanie organizacyjne niewiadome), miał imię zakonne (pseudonim organizacyjny) Zygmunt Mariański; 24 XII 1939 był współzałożycielem polskiej loży «Kopernik» w Paryżu, lecz Wielka Loża Francji do której ta placówka przystąpiła, uznała go za wolnomularza nieregularnego i jego członkostwa w loży «Kopernik» nie zatwierdziła". L. Hass, Wolnomularze polscy w kraju i na świecie 1821-1999. Słownik biograficzny, Warszawa 1999, s. 308-309. 
Kodeks karny obowiąujący tymczasowo w Rzeczypospolitej Polskiej na ziemiach b. zaboru rosyjskiego, t. 3, cz. XX-XXXVII, red. W. Makowski, Warszawa 1922.

Kodeks karny wojskowy: $z$ dodaniem ustaw i przepisów wprowadczych, przechodnich i uzupetniających oraz komentarza, red. W. Makowski, Warszawa 1920.

Ustawa z 6 VII 1923 r. w przedmiocie amnestji z powodu uznania granic Rzeczypospolitej, (Dz. U. z 1923 r., NR 70, poz. 555).

\section{Wspomnienia}

Dowbor-Muśnicki J., Moje wspomnienia, Poznań 2013.

Macesowicz-Majewski D., Łączność w 1 Korpusie Polskim, „Wiarus”, 1937 nr 25.

Wańkowicz M., Strzępy epopei: Szpital w Cichiniczach; Wrzesień żagwiący; Po klęsce, Warszawa 2009.

\section{Monografie i opracowania}

Bagiński H., Wojsko Polskie na Wschodzie: 1914-1920, Warszawa 1990.

Hass L., Wolnomularze polscy w kraju i na świecie 1821-1999. Słownik biograficzny, Warszawa 1999.

Introvigne M., Rosicrucianism III: 19th-20th century [w:] Dictionary of Gnosis \& Western Esotericism, red. W. J. Hanegraaff, Leiden-Boston 2006.

Irving D., Wypadek. Śmierć generała Sikorskiego, Pruszków 2000.

Kasprzycki R., Dezercje i unikanie służby w Wojsku Polskim w latach 1918-1939, „Dzieje Najnowsze” 2016, nr 3, s. 87-106.

Krok T., Antymasońska komórka episkopatu Polski (1946-1952), Łomianki 2018.

Kubiatowski J., Zygmunt Włodzimierz Tarło-Maziński [w:] Polski słownik biograficzny, red. E. Rostworowski, t. 15, Wrocław 1975.

Lipiński W., Walka zbrojna o niepodległość Polski w latach 1905-1918, Warszawa 1990. Łagosz Z., Czesław Czyński. Czarny adept, Warszawa 2017.

Łepkowski T., Wolna szkoła polska w okupowanej Francji. Historia Gimnazjum i Liceum im. Cypriana Norwida w Villard-de-Lans 1940-1946, Warszawa 1990.

Nechaev S. Y., Russkie v Latinskoj Amerike (ros.), Moskwa 2010.

Tomaszewski P., Działalność i ideologia Związku Synarchicznego w latach 1924-1939

[w:] Historia i polityka, t. 4, red. H. Stys, Torun 2006.

Woods W.H., Poland: Eagle in the East: A surveyof modern times, Nowy Jork 1968.

\section{STRESZCZENIE}

\section{Tomasz Krok, Przypadek dezercji dowódcy oddziału radiotelegraficznego w I Korpusie Polskim w Rosji Zygmunta Włodzimierza Tarły-Mazińskiego}

Włodzimierz Zygmunt Tarło-Maziński był pierwszym dowódcą oddziału radiotelegraficznego I Korpusu Polskiego. Był absolwentem kursów inżynieryjnych w Pawłowskiej Szkole Wojskowej oraz Oficerskiej Szkole Elektrotechnicznej w Piotrogrodzie (1915). Pełnił stanowiska: naczelnika szkoły w oddziałach radiotelegraficznych armii rosyjskiej, wykładowcy elektro- i radiotechniki na oficerskich 
kursach przy sztabie Frontu Zachodniego oraz dowódcy korpusowego oddziału radiotelegraficznego. W 1917 r. otrzymał funkcję wojskowego inżyniera radiotechnika. W tym okresie wydał podręczniki w języku rosyjskim: Zapiski po radiotelegrafi (1915) i Elementarnaja radiotelegrafija (1917), które zostały wydane później po polsku jako: Elementarna radiotelegrafia i radiotelefonia $z$ pobieżnym kursem elektrotechniki (1917) oraz Zasady radiotelegrafii (1919). Były to pierwsze polskie publikacje dotyczące radiotelegrafii wojskowej. Jesienią $1917 \mathrm{r}$. wszedł w skład tworzących się w Rosji polskich sił zbrojnych, gdzie w stopniu ppor. został pierwszym dowódcą oddziału radiotelegraficznego i komendantem szkoły radiotelegraficznej przy sztabie I Korpusu Polskiego. Artykuł opisuje kulisy jego niesubordynacji względem rozkazów dowódcy I Korpusu Polskiego na podstawie materiałów archiwalnych Oddzielnej Radiotelegraficznej Grupy oraz Oficerskiego Trybunału Orzekającego.

Słowa kluczowe: I Korpus Polski, Zygmunt Włodzimierz Tarło-Maziński, dezercje

\section{SUMMARY}

\section{Tomasz Krok, The case of the desertion of the commander of the radiotelegraphy unit of the Polish First Corps in Russia Zygmunt Włodzimierz Tarło-Maziński}

Włodzimierz Zygmunt Tarło-Maziński was the first commander of the radiotelegraphy unit of the Polish First Corps. He was a graduate of engineering courses at the Pavel Military School and the Officer Electrotechnical School of Electrotechnology in Petersburg (1915). He held the following positions: headmaster of the school in the Russian army's radiotelegraphy units, lecturer of electrical and radio engineering at officer courses at the Western Front staff, and corps commander of the radiotelegraphy unit. In 1917 he was appointed military radioengineer. At that time he published textbooks in Russian: Records on Radiotelegraphy (1915) and Elementary Radiotelegraphy (1917), which were later published in Polish as Elementary Radiotelegraphy and Radiotelephony with a Brief Course in Electrical Engineering (Elementarna radiotelegrafia i radiotelefonia $z$ pobieżnym kursem elektrotechniki, 1917) and Principles of Radiotelegraphy (Zasady radiotelegrafi, 1919). These were the first Polish publications on military radiotelegraphy. In the autumn of 1917, he became a member of the Polish Armed Forces that were formed in Russia, where as second lieutenant he became the first commander of the radiotelegraphy unit and the commander of the radiotelegraphy school at the Polish First Corps staff. The article provides a behind-the-scenes description of his insubordination to the orders of the commander of the Polish First Corps, basing on the archives of the Independent Radiotelegraphy Group and the Officer's Adjudication Court.

Keywords: Polish First Corps, Zygmunt Włodzimierz Tarło-Maziński, desertions 


\section{PEЗЮME}

Томаш Крок, Дезертирство командира радиотелеграфного подразделения в Первом польском корпусе в России Зигмунта Влодзимежа Тарло-Мазинского

Влодзимеж Зигмунт Тарло-Мазинский был первым командиром радиотелеграфного подразделения в Первом польском корпусе. Он был выпускником инженерных курсов в Павловской Военной школе и Офицерской электротехнической школе в Петрограде (1915). Он имел следующие должности: начальник училища в радиотелеграфных подразделениях русской армии, преподаватель электро- и радиотехники на офицерских курсах при штабе Западного фронта и командир радиотелеграфного отдела корпуса. В 1917 году он был назначен военным инженером-радиотехником. В период работы на этой должности он опубликовал учебники на русском языке: Записки по радиотелеграфии (1915) и Элементарная радиотелеграфия (1917), которые позднее были изданы на польском языке под следующими названиями: Элементарная радиотелеграфия и радиотелефония с кратким курсом электротехники (1917) и Принципы радиотелеграфии (1919). Это были первые польские публикации по военной радиотелеграфии. Осенью 1917 года он вошел в состав формировавшихся в России польских вооруженных сил, где в звании подпоручика стал первым командиром радиотелеграфного отделения и комендантом радиотелеграфной школы при штабе Первого польского корпуса. Статья освещает закулисье его неповиновения приказам командующего Первым польским корпусом. Материалами для исследования послужили архивы Отдельной радиотелеграфной группы и Офицерского судебного трибунала.

Ключевые слова: Первый польский корпус, Зигмунт Влодзимеж Тарло-Мазинский, дезертирство 
MATERIAŁY ŹRÓDŁOWE

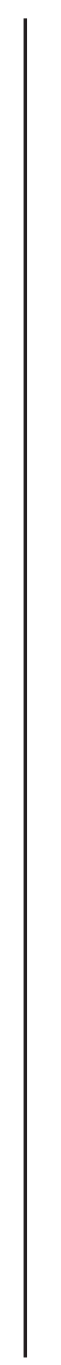

